\title{
Towards a Tyranny of Values?
}

\section{Principles on Defending Checks and Balances in EU Member States}

\author{
Armin von Bogdandy
}

\section{Contents}

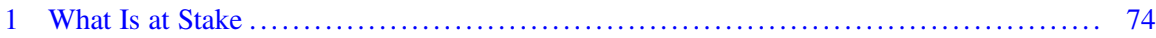

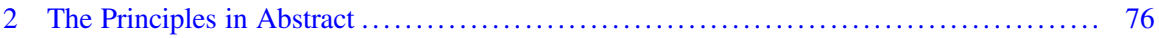

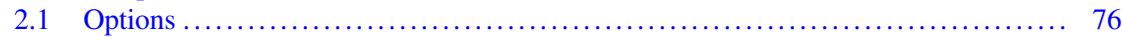

2.2 Grounds Against Defending the Union's Values .......................... 77

2.3 Grounds in Favour of Defending the Union's Values ......................... 78

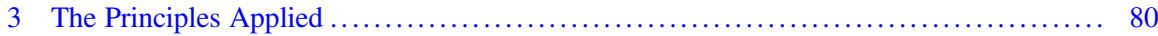

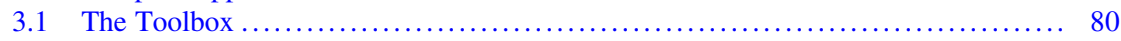

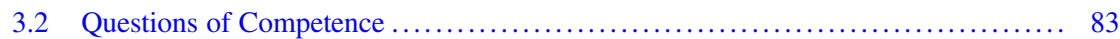

3.2.1 Article 7 TEU in the Order of Competences ....................... 83

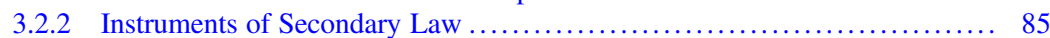

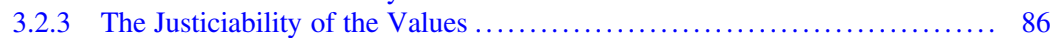

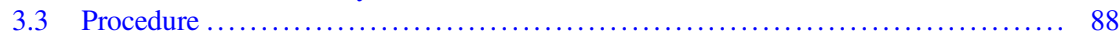

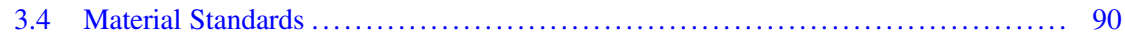

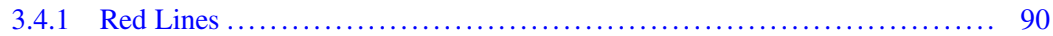

3.4.2 The Comprehensive and Collective Assessment ..................... 93

3.4.3 On the Concreteness of the Risk ............................... 94

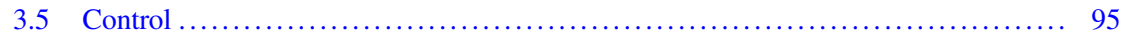

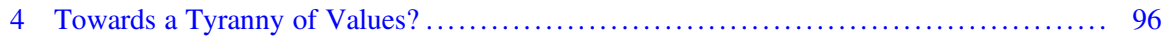

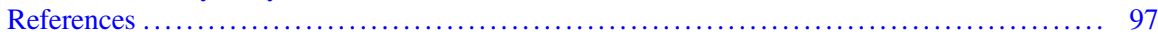

\begin{abstract}
This contribution develops the framework of European reactions to the undermining of checks and balances in EU Member States. It surveys the normative setting with its various institutional options and contrasting constitutional principles and then applies these principles to the panoply of relevant instruments. The building blocks of this framework are competence, procedure, standards, and control. This should help Europe to speak with a principled voice. The contribution shows how
\end{abstract}

A slightly different and longer version has been published in the Common Market Law Review 57 (2020).

A. von Bogdandy $(\triangle)$

Max Planck Institute for Comparative Public Law and International Law, Heidelberg, Germany e-mail: sekreavb@mpil.de 
red lines can be drawn that respect constitutional pluralism, and how any action's legitimacy is enhanced if many institutions undertake it jointly.

\section{What Is at Stake}

In some EU Member States, governing majorities are modifying controlling institutions. These attempts go far beyond the traditional three branches and affect political parties, ombudspersons, the media, NGOs and academia. As such, they critically weaken the domestic checks and balances in a larger sense. ${ }^{1}$ Most consider the value of the rule of law to be endangered, but the values of democracy and of respect for human dignity are no less at stake. ${ }^{2}$ Indeed, political science sees such measures as symptomatic for illiberal democracies, i.e. for authoritarian tendencies. ${ }^{3}$

This book has been triggered by the remodelling of the Polish Judiciary since 2015. ${ }^{4}$ However, the Polish developments are not isolated. Similar tendencies manifest in a series of EU Member States, especially in Hungary. ${ }^{5}$ European constitutionalism is perhaps facing a 'constitutional moment': 6 the decision whether it comprises illiberal democracies or whether it fights them. The first case would herald the end of the European Union's current self-understanding, as 'illiberal democracies' would co-inform the common values of Article 2 TEU in the future. The alternative path requires the Union to counter threats to domestic checks and balances. To achieve this, European constitutionalism must draw and defend 'red lines', which would also imply a considerable constitutional development: European

\footnotetext{
${ }^{1}$ See Ackerman et al. (2011), p. 264.

${ }^{2}$ On the interrelatedness of these values, see already Habermas (1992), p. 109 et seq.; similarly, Möllers and Schneider (2018), p. 97 et seq. Similarly Commission Proposal for a Regulation of the European Parliament and of the Council on the protection of the Union's budget in case of generalised deficiencies as regards the rule of law in the Member States (COM(2018) 324 final), recital (3).

${ }^{3}$ Lauth and Sehring (2009), p. 165; Kailitz and Köllner (2012), p. 11; Merkel (2013), p. 223 et seq.

${ }^{4}$ For an enumeration of particularly problematic measures, see Proposal for a Council Decision on the determination of a clear risk of a serious breach by the Republic of Poland of the rule of law $(\operatorname{COM}(2017) 835$ final), para. 6 et seq.; on the context, Bachmann (2018), p. 9 et seq.; Sadurski (2019).

${ }^{5}$ Halmai (2018a), p. 85; European Parliament resolution of 12 September 2018 on a proposal calling on the Council to determine, pursuant to Article 7(1) of the Treaty on European Union, the existence of a clear risk of a serious breach by Hungary of the values on which the Union is founded (2017/ 2131(INL)). On Romania, see Venice Commission, Romania-Opinion on draft amendments to Law No. 303/2004 on the Statute of Judges and Prosecutors, Law No. 304/2004 on Judicial Organisation, and Law No. 317/2004 on the Superior Council for Magistracy (Oct. 22, 2018), CDL-AD(2018)017; European Parliament resolution of 13 November 2018 on the rule of law in Romania (2018/2844(RSP)).

${ }^{6}$ The concept was coined by Ackerman (1991), p. 6, though with a different thrust.
} 
constitutionalism would gain in profile and develop elements of a militant democracy.

This chapter explores the latter path, which leads into unchartered waters. The legality and the legitimacy of the European actions are disputed. Even the Council of the European Union considers one of the European Commission's instruments inadmissible. ${ }^{7}$ Some voices, not least the European Parliament, regard European actions as too one-sided. ${ }^{8}$ Others accuse the Union of double standards, as it allegedly fails the same values which it demands its Members to respect. ${ }^{9}$ Some hold the European Commission as generally 'unsuited' as a guardian of liberal democracy. ${ }^{10}$

Some even detect in these unchartered waters what Carl Schmitt branded as the 'tyranny of values': a defence of values that destroys the very values it aims to protect. ${ }^{11}$ In April 2017, the Polish ambassador in Berlin announced that Poland respects all European values and that there merely was 'a problem of interpretation. Brussels is far too strongly informed by liberal left-wing ideology. ${ }^{12}$ In similar terms, Viktor Orbán explained his rejection of Frans Timmermans' nomination as President of the Commission by calling him 'an ideological warrior who accepts no diversity, who tolerates no views which diverge from his own and from liberal democracy, and who wants to force his own conception on all EU Member States' ${ }^{13}$ Such positioning is symptomatic. As Uwe Volkmann observes, in today's European society there are 'different worlds of values which only rotate around themselves and hardly ever intersect'. ${ }^{14}$ The predominance of one of these worlds is then quickly considered tyranny by the other.

In the first step, I will explore the constitutional horizon of the question of whether one should intervene in a case such as the Polish one (2). Factors militating against such action are national democracy, the risk of failure, but also the possibility of an unwanted European state (Sect. 2.1), while considerations of the current constitutional self-understanding, Union citizenship and mutual trust speak in favour of such action (Sect. 2.2). The second step develops a legal frame for pertinent instruments of European law, Member States' law and international law (Sect. 3.1),

\footnotetext{
${ }^{7}$ Council Legal Service, Commission's Communication on a new EU Framework to strengthen the rule of law: - compatibility with the Treaties (10296/14).

${ }^{8}$ Mendelski (2016), p. 390; Franzius (2018), p. 382 and 386; Resolution on the need for a comprehensive EU mechanism for the protection of democracy, the rule of law and fundamental rights (2018/2886(RSP)), recital (K).

${ }^{9}$ Weiler (2016), p. 326.

${ }^{10}$ Schorkopf (2016), p. 159; Janse (2019), p. 43.

${ }^{11}$ Schmitt (2011), p. 48 et seq. The expression 'tyranny of values' was first used by Hartmann (1926), p. 524 et seq.

${ }^{12}$ Quoted after Voßkuhle (2018), p. 17.

${ }^{13}$ Press Release, 'They want to make Soros's man the President of the Commission' (2 July 2019), www.kormany.hu/en/the-prime-minister/news/they-want-to-make-soros-s-man-the-president-ofthe-commission.

${ }^{14}$ Volkmann (2018), p. 14.
} 
consisting of the building blocks legal basis (Sect. 3.2), procedure (Sect. 3.3), standards (Sect. 3.4), and control (Sect. 3.5).

\section{The Principles in Abstract}

\subsection{Options}

The European legal space requires that all institutions exercising public authority within its scope respect its fundamental values. Its legal orders have mutually committed themselves to a constitutional core. ${ }^{15}$ This is expressed most clearly in Articles 2, 7, and 49 TEU, but national constitutional law sets out similar requirements. ${ }^{16}$ These requirements are complemented by international law, especially Article 3 Statute of the Council of Europe as well as the ECHR. ${ }^{17}$ These requirements may not be identical, given European constitutional pluralism, but they certainly rest on largely overlapping core values. ${ }^{18}$

At the same time, it is not clear whether and how public institutions are to defend these fundamental values. Article 7 TEU, which stipulates specific mechanisms, provides much discretion: The Union 'may', but is not bound to defend the European values against its Member States. ${ }^{19}$ All the other instruments, too, leave ample scope. $^{20}$ There is legal room for considering various options.

From the perspective of Union law, a first option is to avoid any conflict, to do nothing, and — with liberal optimism — to trust into the self-healing powers of liberal constitutionalism. A second option would be to primarily address authoritarian tendencies in the Council of Europe, thus acknowledging the Council's special role regarding questions of Member State constitutional law. ${ }^{21}$ This would relieve cooperation within the Union from this conflict. A third option for the Union is to adhere to the established scope of Union law und thus avoid the highly conflictual discussion about values. The Commission acted against Hungary in this sense: it brought the disempowerment of the judiciary to the CJEU as an inadmissible

\footnotetext{
${ }^{15}$ For an overview see von Bogdandy (2014), p. 980.

${ }^{16}$ BVerfGE 140, 317 - Identitätskontrolle; The Minister for Justice and Equality v. Celmer, [2018] IEHC 119 (2018).

${ }^{17}$ In detail Uerpmann-Wittzack (2009), p. 131.

${ }^{18}$ Opinion of AG Cruz Villalón in CJEU, Case C-62/14 Gauweiler and Others, ECLI:EU:C:2015:7, para. 61.

${ }^{19}$ Communication from the Commission to the Council and the European Parliament on Article 7 of the Treaty on European Union. Respect for and promotion of the values on which the EU is based (COM(2003) 606 final) p. 6; Ruffert (2016), para. 8.

${ }^{20}$ However, there may also be constellations in which there is a duty to take action, Huber (2017), p. 389.

${ }^{21}$ Tuori (2016), p. 237. On the procedure under Art. 20 (c) Statute of the European Council, see Wittinger (2005), p. 130 et seq.
} 
discrimination of elderly judges under the Anti-Discrimination Directive 2000/78. ${ }^{22}$ As a fourth option, the Union could leave the issue to its Member States. The Member States in turn could act collectively, as in case of the sanctions against Austria, ${ }^{23}$ or individually, e.g., by denying the Member State in question judicial cooperation or by utilising Article 259 TFEU. $^{24}$

Exercising such discretion must be based on valid grounds. The structuring of such grounds is a task of legal doctrine. While such a doctrine cannot recommend any specific outcome, it can rationalise matters. As is the case with most difficult decisions, there are valid reasons both for and against defending the Union's values.

\subsection{Grounds Against Defending the Union's Values}

Powerful arguments suggest caution. One of these, much deployed by the Polish government, refers to the pair of democracy and national identity. Article 2 TEU states democracy as a fundamental value; Article 4 (2) TEU protects the Member States' 'national identities, inherent in their fundamental structures, political and constitutional'. If a democratically elected governing majority modifies these fundamental political and constitutional structures - this most 'sacred' area of national sovereignty-there is strong reason to assume that neither the Union nor other Member States should intervene. From a comparative view, the situation in Poland or in Hungary is far less critical than the one in Russia or Turkey. ${ }^{25}$ Furthermore, understanding the Union's values in an exacting manner would create the need to intervene in many Member States. This can hardly be the intention of the TEU.

Another valid argument is the consideration not to damage the Union. Articles 1 and 3 TEU task the Union to develop policies for the good of its citizens. Any attempt to force an elected government under a common constitution can easily result in explosive conflicts. They may even endanger the constitution itself. ${ }^{26}$ One need only think of the escalation caused by the actions of the Spanish central state against the governing majority of Catalonia. ${ }^{27}$ And European actions against the current governing majority in Poland lack important resources which supported the Spanish central state against the Catalonian government: a clear democratic mandate, a developed national consciousness, and the hard instrument of federal execution. Polish representatives have already declared that they consider European

\footnotetext{
${ }^{22}$ CJEU, Case C-286/12 Commission v. Hungary, ECLI:EU:C:2012:687, para. 24 et seq.; critically Halmai (2017), p. 471.

${ }^{23}$ On this Ahtisaari et al. (2000), para. 116; Schorkopf (2002), Lachmayer (2017).

${ }^{24}$ BVerfGE 140, 317 - Identitätskontrolle; Hirsch Ballin (2016), p. 133; Kochenov (2015), p. 153.

${ }^{25}$ Weiler (2016), p. 314.

${ }^{26}$ Dyzenhaus (2012); comparative Federalism is instructive in this respect, Möllers and Schneider (2018), p. 5 et seq.

${ }^{27}$ García Morales (2018), p. 791 et seq.
} 
actions against their remodelling of the judiciary as illegitimate. ${ }^{28}$ It appears possible that a European defence of values may fail, which might inflict lasting damage on the Union's authority and demonstrate the frailty of the foundations of the common European house. The Union is not built for such conflict: since its 'constitutional moment' of overcoming the French 'empty seat', the search for consensus is key to its operation. $^{29}$

But success, too, might plunge the Union into serious trouble. If the Union prevails over the combative Polish government, this would imply an enormous proof of power. The Union would significantly gain in stature vis-à-vis its Member States should it succeed in transforming its instruments, so far widely considered as rather ineffective, into a kind of effective federal execution. ${ }^{30}$ This could be regarded as a huge step towards the EU's becoming a federal state, since what the Union primarily lacks in this regard is precisely such power. Such a prospect of Staatswerdung could cause a backlash from many Member States, which might equally endanger the Union. For all these reasons, the Union's hesitations should not be misconceived as mere opportunism. ${ }^{31}$

\subsection{Grounds in Favour of Defending the Union's Values}

At the same time, there are substantial legal grounds for the Union to defend European values. Three of them appear particularly pertinent: the European selfunderstanding as a community of values, Union citizenship and the principle of mutual trust. ${ }^{32}$

A first reason for the Union to defend its values results from its selfunderstanding, stipulated in the Treaties, as a liberal-democratic peace project. According to Article 2 TEU, the Union has been 'founded' on the respect for these values. This applies not only to the Union's supranational institutions, but also to its Member States. Article 2 TEU expresses standards for any public action in the European legal space. ${ }^{33}$ Respecting and promoting these values is the key requirement for membership, as stipulated in Article 49 TEU. The term 'value' underlines the character of these principles as 'supreme and final normative

\footnotetext{
${ }^{28}$ See the statement by Polish Prime Minister Mateusz Morawiecki, quoted after Steinbeis (2018); the Vice President of the Polish Constitutional Court has announced that he would consider any judgment of the Court of Justice of the European Union against Poland as illegitimate, see Muszyński (2018).

${ }^{29}$ van Middelaar (2016), pp. 107 et seq., 120.

${ }^{30}$ The Polish compliance with the interim measures ordered by the CJEU in Case C-619/18, Commission v. Poland, with regard to the Supreme Court might be an indication.

${ }^{31}$ Cf., e.g., Kochenov and Pech (2016), p. 1062.

${ }^{32}$ On the legal grounds for intervention Closa et al. (2014), pp. 5-7; Hillion (2016), pp. 60-64.

${ }^{33}$ In detail von Bogdandy (2010), p. 13 et seq.
} 
grounds' ${ }^{34}$ In Article 2 TEU, all Member States declare who they are and what they stand for; they articulate the deep logic of their institutional practice and the moral convictions of their citizens. In short: Article 2 TEU positivises the Union's selfunderstanding as a community of values.

In the light of substantiated evidence that Polish measures violate European values, a European silence would speak volumes. It would question this very community: the common axiological basis would appear either as an unfounded illusion or as a foundation that includes developments such as the Polish ones. In both cases, the self-understanding cultivated so far would hardly prove sustainable. The distance to Trump's USA would diminish. The Union would face a severe identity crisis.

Another legal ground results from the Union's mandate to protect all individuals in the European legal space, which includes protecting Polish citizens against their own government. ${ }^{35}$ The CJEU says that 'Article 20 TFEU precludes national measures which have the effect of depriving citizens of the Union of the genuine enjoyment of the substance of the rights conferred by virtue of their status as citizens of the Union'. ${ }^{36}$ This includes the 'essence' of EU fundamental rights, which is protected by Article 2 TEU. In L.M. (Deficiencies in the system of justice), which deals precisely with the Polish measures, the CJEU emphasized this link between the essence of a Charter right (the right to a fair trial and an impartial court in Article 47 (2) CFR) and Article 2 TEU and allowed a Polish national to invoke this essence against the internal developments in his home state. ${ }^{37}$ With this logic, presumably any violation of a value can somehow be tried in court. ${ }^{38}$ This is a kind of 'reverse' Solange doctrine: outside the scope of application of the Charter of Fundamental Rights, Member States remain autonomous with respect to fundamental rights, as long as they guarantee the standard of Article 2 TEU. ${ }^{39}$ If this standard is undercut, all public institutions in the European legal space must enforce the essence of the Union's fundamental rights against any measures of the Member State concerned. ${ }^{40}$

The Union's steps against Poland are important not only on a normative, but also on a cognitive level. ${ }^{41}$ Such steps disprove the assumption that all Polish citizens stand with the governing majority. Indeed, many Polish citizens fight for liberal

\footnotetext{
${ }^{34}$ Luhmann (1993), p. 19; cf. also Habermas (1992), p. 311 et seq.

${ }^{35}$ Franzius (2018), p. 384.

${ }^{36}$ CJEU, Case C-34/09 Ruiz Zambrano, ECLI:EU:C:2011:124, para. 42.

${ }^{37} \mathrm{CJEU}$, Case C-216/18 PPU Minister for Justice and Equality, ECLI:EU:C:2018:586. The term 'deficiency' can be found in the case's denomination by the Advocate General as well as in the press release, CJEU, Press Release No. 113/18. In detail von Bogdandy and Spieker (2019).

${ }^{38}$ Spieker (2019), Schmidt and Bogdanowicz (2018), p. 1090.

${ }^{39}$ In detail von Bogdandy et al. (2012), p. 489; von Bogdandy et al. (2015), p. 235; von Bogdandy and Spieker (2019).

${ }^{40}$ Cf. the contributions in Steinbeis et al. (2015), Croon-Gestefeld (2017), p. 371; Blauberger (2016), p. 280; Russo (2014), Kochenov (2013), p. 145.

${ }^{41}$ Mälksoo (2009), p. 653.
} 
democracy in their country. ${ }^{42}$ In doing so, they refer to their status as citizens of the Union, as is shown by the European flag accompanying government-critical demonstrations. For Union citizenship, this might be a historic moment: it gains genuine political weight.

A third reason for the Union to defend its values is the principle of mutual trust. In the L.M. (Deficiencies in the system of justice) judgment, the Court made a clear point: measures like the Polish ones endanger the fundamental structure of the Union because they undermine mutual trust, without which vital areas of European cooperation cease to function. ${ }^{43}$ The principle of mutual trust states: all Member States must trust that all Member States respect Union law and its fundamental rights in particular. $^{44}$ The status quo of integration can hardly be maintained without mutual trust. ${ }^{45}$ But such trust requires defending the values on which it stands. ${ }^{46}$

\section{The Principles Applied}

\subsection{The Toolbox}

Many instruments might be used to defend European values. They are of diverse legal nature (political, administrative and judicial, binding and non-binding), they pertain to different legal orders and they are applied by different, sometimes even competing institutions, such as a constitutional court and the CJEU. That calls for a coordinating legal doctrine comprehending several legal orders.

Such a doctrine should not force the different instruments into a Procrustean bed. Instead, it should elaborate their diversity while indicating how to connect them as part of a functional tool box. Coordinated actions are more promising, whereas uncoordinated ones might be counterproductive. In more general terms: a clear and univocal reaction of the many European voices is essential for the protection of the Union's values.

Instruments of Union law are at the centre of attention. ${ }^{47}$ This is justified insofar as action by the Union reduces the pressure on Member States to take steps on an individual level: the latter, e.g., a reprisal, can be even more explosive than pressure

\footnotetext{
${ }^{42}$ The current governing majority only received $37.58 \%$ of all votes cast, with a voter turnout of $50.92 \%$.

${ }^{43}$ CJEU, Minister for Justice and Equality, supra note 37, para. 35. In detail, Regan (2018), p. 231.

${ }^{44}$ CJEU, Opinion 2/13 Adhésion de l'Union à la CEDH, ECLI:EU:C:2014:2454, para. 191; Lenaerts (2017), p. 805.

${ }^{45}$ CJEU, Case C-411/10 N.S. and Others, ECLI:EU:C:2011:865, para. 83; in detail von Bogdandy (2018), p. 487.

${ }^{46}$ CJEU, Case C-578/16 PPU C.K. and Others, ECLI:EU:C:2017:127, para. 95.

${ }^{47}$ For an overview see Closa et al. (2014) as well as the accounts given in Closa and Kochenov (2016) and Jakab and Kochenov (2017).
} 
by the Union. ${ }^{48}$ Among the instruments of the political institutions, measures taken under Article 7 TEU, the Commission's Rule of Law Framework and the rule of law dialogue of the Council are at the forefront. ${ }^{49}$ The Commission's Justice Scoreboard 2018 has become a supervisory instrument, too ${ }^{50}$ as has the Commission's Country Report on Poland within the framework of the European Semester. ${ }^{51}$ Regarding some Member States, the Union disposes of additional instruments. The Cooperation and Verification Mechanism in the Treaties of Accession with Bulgaria and Romania is meant to 'see the two countries develop the effective administrative and judicial systems needed' ${ }^{52}$ The Treaty of Accession with Croatia contains a similar instrument. ${ }^{53}$ Further instruments are being planned: the Commission wants to make funding subject to respecting EU values ${ }^{54}$ and to launch an 'EU Justice, Rights and Values Fund' with an overall budget allocation of 947 million EUR. ${ }^{55}$

In the framework of the European Parliament, there are the plenary debate, the law on sanctioning radical political parties ${ }^{56}$ as well as disciplining instruments within Europe's political alliances. ${ }^{57}$

\footnotetext{
${ }^{48}$ Müller (2015), p. 145.

${ }^{49}$ Conclusions of the Council of the EU and the Member States meeting within the Council on ensuring respect for the rule of law (16134/14).

${ }^{50} \mathrm{Cf}$. Communication from the Commission to the European Parliament, the Council, the European Central Bank, the European Economic and Social Committee and the Committee of the Regions. The 2018 EU Justice Scoreboard (COM(2018) 364 final), p. 4 et seq. On the Justice Scoreboard, Dori (2015), Jakab and Lorincz (2017).

${ }^{51}$ Country Report Poland 2018 accompanying the document Communication from the Commission to the European Parliament, the Council, the European Central Bank and the Eurogroup: 2018 European Semester: Assessment of progress on structural reforms, prevention and correction of macroeconomic imbalances, and results of in-depth reviews under Regulation (EU) No 1176/2011 (SWD(2018) 219 final), pp. 3, 29.

${ }^{52} \mathrm{Cf}$. the corresponding reports by the Commission, most recently Report from the Commission to the European Parliament and the Council, On Progress in Bulgaria under the Cooperation and Verification (COM(2018) 850 final); Vachudova (2016), p. 270; Carp (2014), p. 1.

${ }^{53}$ Act concerning the conditions of accession of the Republic of Croatia and the adjustments to the Treaty on European Union, the Treaty on the Functioning of the European Union and the Treaty establishing the European Atomic Energy Community (2012) OJ L112/21, Art. 36. In detail, Łazowski (2012), pp. 33-36.

${ }^{54}$ Commission Proposal for a Regulation of the European Parliament and of the Council on the protection of the Union's budget in case of generalised deficiencies as regards the rule of law in the Member States (COM(2018) 324 final), Art. 2; see also Halmai (2018b).

${ }^{55}$ Annex to the Communication from the Commission to the European Parliament, the European Council, the Council, the European Economic and Social Committee and the Committee of the Regions, A modern budget for a Union that protects, empowers and defends: The multiannual financial framework for 2021-2027 (COM(2018) 321 final), p. 48.

${ }^{56}$ Regulation (EU, Euratom) 1141/2014 on the statute and funding of European political parties and European political foundations (2014) OJ L317/1, art. 3 and art. 6.

${ }^{57}$ Art. 9 of the European People's Party Statutes, for example, permits the exclusion of both individual and Member State political parties, but does not define a reason for exclusion. Similar provisions are contained in Art. 16 Statutes of the Alliance of Liberals and Democrats for Europe Party.
} 
Then there are the courts. ${ }^{58}$ Unlike political bodies, they cannot avoid making decisions. The CJEU can be called upon to decide via the infringement and the preliminary ruling procedures; both can lead to severe financial sanctions. Furthermore, the CJEU can support actions of political institutions: an important example for this is the role it attributes to the qualifications made in the Commission's proposal to institute a procedure under Article 7 TEU. ${ }^{59}$ Accordingly, such a proposal is sensible even when the Council and the European Council are unlikely to act.

The Union's institutions apart, those of the Member States can also defend European values. In this context, the tool box of international law is to be considered, from retaliatory measures to the mechanisms of the Vienna Convention on the Law of Treaties ${ }^{60}$ to the extreme and contested option of an eventual humanitarian intervention in case a state turns to state terrorism. ${ }^{61}$ The governments of the Member States can coordinate such international instruments, as was the case against Austria in $2000 .^{62}$ They could also consider, and threaten, to advance integration among themselves, excluding the countries that do not conform with the values. ${ }^{63}$

Member State courts, too, dispose of relevant instruments. They can defend European values against their own state in the light of a 'reverse Solange' doctrine ${ }^{64}$ or against another Member State in the light of a 'horizontal Solange' doctrine. ${ }^{65}$ The CJEU can support them in this via preliminary rulings. An important question is to what extent national courts can proceed independently from Union law on such matters. ${ }^{66}$

Other pertinent measures are those of the Council of Europe, especially recommendations issued by its political institutions or by the Commission for Democracy through Law (Venice Commission), as well as decisions of the ECtHR. ${ }^{67}$ While the Council of Europe far exceeds the EU-centred European legal space, its relevance inside the European legal space flows from Article 6 (3) TEU, Article 52 (3) and Article 53 of the CFR. On an operative level, there is a close institutional connection. ${ }^{68}$

\footnotetext{
${ }^{58}$ On this, see in particular Huber (2017), p. 409 et seq.

${ }^{59} \mathrm{CJEU}$, Minister for Justice and Equality, supra note 37, paras. 69 et seq.

${ }^{60}$ In detail, see Binder (2013).

${ }^{61}$ Crawford (2013), p. 931; International Law Association (2018), p. 20 et seq.

${ }^{62}$ In detail, see Schorkopf (2002), p. 77.

${ }^{63}$ Franzius (2018), p. 388.

${ }^{64}$ On this, see above, Sect. 2.3. See also the presently pending references on a preliminary ruling in the cases Miasto Lowicz v Skarb Państwa - Wojewoda Łódzki (C-558/18); Prokuratura Okregowa w Ptocku v VX, WW, XV (C-563/18); Prokuratura Rejonowa w Stubicach (C-623/18).

${ }^{65}$ See in particular Canor (2013); a first case of application is the judgment of the Irish High Court in the Celmer case, supra note 16.

${ }^{66} \mathrm{As}$ indicated in BVerfGE 140, 317 - Identitätskontrolle.

${ }^{67}$ Cf. on the Venice Commission, Nergelius (2015), p. 291; Grabenwarter (2018), p. 21.

${ }^{68}$ von Bogdandy (2008), p. 69 et seq.
} 
Given that this legal framework comprises instruments of Union law, international law and the law of the Member States, it pertains to European law and not simply to Union law, international or domestic law alone. ${ }^{69}$ In the tradition of public law thinking, such a doctrinal framework is to contribute to legal instruments promoting their legitimacy as well as their efficacy. Its most important building blocks are legal basis (Sect. 3.2), procedure (Sect. 3.3), the material standards (Sect. 3.4), and control (Sect. 3.5).

\subsection{Questions of Competence}

Any action to protect European values is prone to escalation. Therefore, it should be in the hands of institutions that can shoulder such a responsibility and manage conflicts. The first aspect responding to this concern is the requirement of a legal basis, in many cases even the need of a specific competence. ${ }^{70}$ Thus, the first question is to verify whether its adoption and use are supported by a legal basis.

\subsubsection{Article 7 TEU in the Order of Competences}

Article 7 TEU plays a key role in this respect, as it might bar other reactions to systemic deficiencies under Article 2 TEU. In this case, the defence of the values would be completely under the control of the governments of the Member States, united in the Union's institutions. Responsibility, therefore, would be crystal clear. The drawback is that the extremely high requirements of Article 7 TEU might leave EU values without defence. Besides this consequentialist consideration, doctrinal arguments likewise militate against interpreting Article 7 TEU as an exclusive mechanism.

A first issue is whether Article 7 TEU prohibits pertinent measures by Member States. Article 3 TFEU does not list Article 7 TEU. Article 4 TFEU, which enumerates the main areas of shared responsibilities, does not feature Article 7 TEU either. However, it lists the space of freedom, security and law. Hence, there could be an argument to assume precedence of measures of Union law vis-à-vis a defence by Member States. Then there is Article 344 TFEU. ${ }^{71}$

The CJEU's case-law seemed to point towards pre-emption, especially in cases like Melloni, which excluded the unilateral enforcement of one Member State's

\footnotetext{
${ }^{69}$ On this understanding of European law, see in detail already Mosler (1968), p. 481 et seq.; von Bogdandy (2016), p. 589.

${ }^{70}$ Bast (2006), p. 30 et seq.; Bast (2018), para. 13 et seq.

${ }^{71}$ On the expansive interpretation of this clause, see CJEU, Case C-459/03 Commission v. Ireland (Mox Plant), ECLI:EU:C:2006:345, paras. 123 et seq.
} 
constitutional principles against another. ${ }^{72}$ After the German Federal Constitutional Court emphasized its competence to protect the constitutional identity of the German Basic Law against measures taken by other Member States, too ${ }^{73}$ the CJEU has acknowledged that European law leaves room for the national defence of fundamental principles. ${ }^{74}$ Since the European values of Article 2 TEU and the identity-informing fundamental principles of the Member State constitutions widely overlap ${ }^{75}$ neither the competences of Article 7 TEU nor other instruments of Union law block Member State institutions from defending European values, according to this case-law. This corresponds to the logic of the European legal space not to monopolise a central question such as value defence in one institution. The considerable need for coordination must be met with other means. ${ }^{76}$

The second issue is whether Article 7 TEU bars actions taken by other Union institutions. Article 7 TEU does not contain an explicit statement as to whether other Union institutions may defend European values using other instruments. The general rules apply. It is well established that a specific procedure designed to deal with a certain problem does not exclude developing other instruments, ${ }^{77}$ a core statement since the Van Gend en Loos judgment. ${ }^{78}$ Accordingly, it is, in principle, admissible to develop new instruments, ${ }^{79}$ such as the Commission's Rule of Law Framework, or the Justice Score Board.

Nevertheless, Article 7 TEU plays a role. Its wording, the inclusion of the European Council and the extremely laborious procedure in Article 7 TEU indicate that it stipulates the most intensive form of defence of values. Therefore, the Union lacks any competence for developing stronger instruments. Hence, the expulsion of a Member State ${ }^{80}$ or the dismissal of its government, an instrument the Spanish government used against the Catalan government, are off limits. ${ }^{81}$ All instruments complementing those of Article 7 TEU in defending the values of Article 2 TEU must be less severe. ${ }^{82}$

\footnotetext{
${ }^{72}$ CJEU, Case C-399/11 Melloni, ECLI:EU:C:2013:107.

${ }^{73} \mathrm{BVerfGE}$ 140, 317 - Identitätskontrolle.

${ }^{74}$ At least within the scope of fundamental rights, CJEU, Joined Cases C-404 and C-659/15 PPU Aranyosi and Căldăraru, ECLI:EU:C:2016:198.

${ }^{75} \mathrm{Cf}$. Opinion of Advocate General Cruz Villalón in CJEU, Gauweiler and Others, supra note 18.

${ }^{76}$ On this Sects. 3.3 and 3.4.

${ }^{77}$ Bast (2006), pp. 60-63.

${ }^{78} \mathrm{CJEU}$, Case C-26/62 Van Gend en Loos v. Administratie der Belastingen, ECLI:EU: C:1963:1, p. 11.

${ }^{79}$ Bast (2006), pp. 42-67. Cf. also Brauneck (2019), pp. 37 and 59.

${ }^{80}$ On this, see the proposal by Stein (1998), p. 890; Blagoev (2011), p. 191.

${ }^{81}$ Recently in Spain under Article 155 Spanish Constitution. On this, García Morales (2018).

${ }^{82}$ In this sense also CJEU, Minister for Justice and Equality, supra note 37; see also below, Sect. 3.4.
} 


\subsubsection{Instruments of Secondary Law}

So far, action under Article 7 TEU is paralyzed by the Council and the European Council. Can other institutions defend the values through other instruments? As has been shown, Article 7 TEU does not prohibit other instruments. But any new instrument needs an appropriate legal basis. This requirement results from the necessity to legitimise any action of public authorities, including 'soft' measures. ${ }^{83}$ A new instrument might even need a specific competence. ${ }^{84}$

With a view to the European Parliament, its general tasks allow it to discuss any systemic deficiencies in the Member States, ${ }^{85}$ and it has done so for a long time. Its resolutions have gained public attention. However, they have not had much impact yet.

Measures taken by the other institutions could yield more powerful results, which is why the law is more demanding than with respect to the European Parliament, as has been shown by developments in other fields. The CJEU has declared Commission Communications invalid due to lack of competence (!). ${ }^{86}$ The Court's requirement of a legal basis is particularly striking in the OMT procedure, whose subject was the mere announcement of a new instrument for purchasing bonds by ECB president Mario Draghi. $^{87}$

The legal service of the Council has disputed the power of the Commission to establish the rule of law mechanism; ${ }^{88}$ here, the general problem comes to the fore. However, the admissibility of this mechanism flows from the Commission's right to make requests under Article 7 TEU as well as its general role of a guardian of the Treaties according to Article 17 (1) TEU. On that basis, the Commission can also examine whether the Member States respect the values of Article 2 TEU. The competence to issue corresponding recommendations follows from Article 292 4th sentence TFEU. ${ }^{89}$ These considerations also support the Justice Score Board.

Similar questions have emerged in the Council of Europe. One need only think of the sanctions imposed by its Parliamentary Assembly against Russian

\footnotetext{
${ }^{83}$ See Nettesheim (2018), para. 200; Senden (2004), p. 478 et seq. On the legal boundaries, von Bogdandy et al. (2015), pp. 273-275.

${ }^{84}$ In detail Bast (2006), para. 23 et seq.

${ }^{85}$ Bast (2006), para. 28.

${ }^{86}$ CJEU, Case C-57/95 France v. Commission, ECLI:EU:C:1997:164; CJEU, Case C-233/02 France v. Commission, ECLI:EU:C:2004:173, para. 40; Opinion of Advocate General Michal Bobek in CJEU, Case C-16/16 P Commission v. Belgium, ECLI:EU:C:2017:959.

${ }^{87}$ Opinion of Advocate General Cruz Villalón in CJEU, Gauweiler and Others, supra note 18.

${ }^{88}$ Commission's Communication on a new EU Framework to strengthen the rule of law: compatibility with the Treaties (10296/14).

${ }^{89}$ Giegerich (2015), pp. 535-536; Toggenburg (2013).
} 
parliamentarians since the annexation of the Crimea. ${ }^{90}$ Another example are the opinions from the Venice Commission issued without a request from the Convention state concerned. ${ }^{91}$ All these measures constitute reactions to systemic problems and can be treated analogously to the considerations on the instrument tool box of Union law.

\subsubsection{The Justiciability of the Values}

The defence of values by political institutions has not been very effective so far. As so often in the history of integration, the question arises whether the judiciary can compensate for this. For the CJEU, this is a question of its powers within the procedures of the Articles 257, 258 and 267 TFEU. Article 7 TEU does not block these procedures; Article 269 TFEU only determines that the Court cannot review the material prerequisites of Article 7 TEU. Given the lack of any explicit ban and the CJEU's general role in the union of law, there is good reason to assume that values can play a role in procedures under the Articles 257, 258 and 267 TFEU. ${ }^{92}$

The actual crux is the justiciability of the values of Article 2 TEU. The term value can be interpreted as the Treaty makers' attributing a vagueness to Article 2 TEU that excludes judicial application. ${ }^{93}$ Arguments relating to the separation of powers might support this conclusion. The judicial application of values would immensely extend the courts' sphere of power to highly political conflicts. ${ }^{94}$ All of this can be avoided by considering the values not to be justiciable.

However, following the established path of European Union law, the Commission and the CJEU have legally and credibly condensed the values of Article 2 TEU so that they have become accessible to judicial decision making, the value of the rule of law being at the centre. The most important path to condensing the values lies in connecting these values to fundamental rights and the well-established principles of the common constitutional traditions. ${ }^{95}$ The effort has proven successful: even from the Polish 'White paper on the reform of the Polish judiciary'—which presents the highly controversial changes in the Polish judiciary as conforming to the values-

\footnotetext{
${ }^{90}$ Reconsideration on substantive grounds of the previously ratified credentials of the Russian delegation (Resolution 1990 (2014) Final version) as well as the extension through: Challenge, on substantive grounds, of the still unratified credentials of the delegation of the Russian Federation (Resolution 2034 (2015) Final version); Steininger (2018), Henderson (2018), p. 393.

${ }^{91}$ von Bogdandy and Sonnevend (2015).

${ }^{92}$ In detail, Spieker (2019), Schmidt and Bogdanowicz (2018), pp. 1069-1073; Hilf and Schorkopf (2017), para. 46; Hillion (2016), p. 59; Franzius (2018), p. 381 (386); a different attitude is expressed by Levits (2018), p. 239 (262); Nicolisi (2015), p. 613 (643); Martenczuk (2018), p. 41 (46).

${ }^{93}$ Kochenov and Pech (2018), p. 512 (520); Nicolisi (2015), p. 643.

${ }^{94}$ On the German discussion, Schmitt (2011), Böckenförde (1990), p. 25.

${ }^{95}$ CJEU, Minister for Justice and Equality, supra note 37. On the common constitutional traditions, see Cassese (2017), p. 939 et seq.; Graziadei and de Caria (2017), p. 949 et seq.
} 
one can gather that European values have come to permit concrete legal assessment. ${ }^{96}$ Two Commission communications in 2019 bring these developments together. $^{97}$

Two judgments by the CJEU from 2018 are leading the way for the judicial operationalisation of the value of the rule of law. In the case Associação Sindical dos Juizes Portugueses (ASJP), the Court has operationalized the value of the rule of law by applying it together with another, specific and directly applicable Treaty provision. In the crucial passage, the Court states that 'Article 19 TEU [. . .] gives concrete expression to the value of the rule of law stated in Article $2,{ }^{98}$ In the L.M. (Deficiencies in the system of justice) case, it enabled individuals to defend European values. ${ }^{99}$ The case dealt with the protection of the separation of powers via an independent judiciary, and it accomplished this via the fundamental right to an impartial court and to a fair trial. The Court's approach is reminiscent of the German Federal Constitutional Court's Maastricht decision, which also made a fundamental principle (democracy) justiciable via an individual right (right to vote, Article 38 (1) of German Basic Law). ${ }^{100}$ Since the L.M. case, the "vigilance of individuals concerned to protect their rights' might also protect European values. ${ }^{101}$

Accordingly, the courts, including Member State courts, can decide on the values of Article 2 TEU. ${ }^{102}$ The values have become judicially applicable though the doctrinal paths may vary. ${ }^{103}$ This expansion of judicial competence mirrors the importance of the values and the judiciary's general role in the European legal space. By now, there is a judicial line of defence beyond the political rationality of Article 7 TEU.

The judicial applicability of European values means that constitutional courts, too, can defend them. However, in many Member States, Union law does not provide a standard of constitutional review, according to most constitutional courts concerned. ${ }^{104}$ Some reasons for this reticence are of a rather more legal nature, especially the fact that Union law lacks constitutional rank in the domestic sphere. Other considerations are of a more political nature, in particular the consideration

\footnotetext{
${ }^{96}$ Chancellery of the Prime Minister of Poland (2018), para. 166.

${ }^{97}$ Communication from the Commission to the European Parliament, the European Council, the Council, the European Economic and Social Committee and thee Committee of the Regions, Strengthening the rule of law within the Union. A blueprint for action, COM/2019/343 final.

${ }^{98}$ CJEU, Case C-64/16 Associação Sindical dos Juízes Portugueses, ECLI:EU:C:2018:117.

${ }^{99} \mathrm{CJEU}$, Minister for Justice and Equality, supra note 37, para. 47 et seq.

${ }^{100}$ BVerfGE, 123, 267 - Lissabon; BVerfGE, 89, 155 - Maastricht; see, critically, Nettesheim (2009), p. 2869.

${ }^{101}$ CJEU, Van Gend en Loos v. Administratie der Belastingen, supra note 78.

${ }^{102}$ See, especially, CJEU, Associação Sindical dos Juízes Portugueses, supra note 98; CJEU, Minister for Justice and Equality, supra note 37; now also CJEU, Case C-619/18 Commission/ Poland, ECLI:EU:C:2019:531, para. 47; AG Tanchev, Opinion in Case C-192/18 - Commission/ Poland, para. 71; AG Tanchev, Opinion in Joined Cases C-585, C-624 and C-625/18 - A.K. (Indépendance de la chambre disciplinaire de la Cour suprême), para. 77.

${ }^{103}$ von Bogdandy and Spieker (2019).

${ }^{104}$ In detail, Paris (2017), p. 798 et seq.; Mengozzi (2015), p. 707; Lacchi (2015), p. 1663.
} 
that the constitutional courts' abstention from applying Union law facilitates a division of tasks that reduces conflicts between the CJEU and the constitutional courts. $^{105}$

These considerations meet with objections. There is enough interpretive scope to include Union law into the purview of constitutional courts, ${ }^{106}$ as just decided by the so far reticent German Federal Constitutional Court. ${ }^{107}$ Substantively, such a step would result in a more effective implementation of Union law. Moreover, it would strengthen the constitutional courts themselves: they could take a more active role in interpreting Union law and shaping the European legal space. ${ }^{108}$

\subsection{Procedure}

The pivotal point of the CJEU's L.M. (Deficiencies in the system of justice) judgment is the fundamental right to a fair trial, Article 47 (2) CFR. It expresses a general legal principle which, in the European legal space, protects not only individuals, but also public authorities. ${ }^{109}$ Moreover, it applies not only in judicial procedures, but whenever a legal subject is faced with the exercise of public authority, ${ }^{110}$ especially when substantial interests are at stake. ${ }^{111}$ This is the case with conflicts concerning systemic deficiencies: the interests in question here are the national reputation, the interest of prosecution, the effective functioning of the national judiciary, financial interests as well as the participation in institutions of the Union. A fair procedure is important not only for the legitimacy of any specific decision, but also for general cohesion in Europe. ${ }^{112}$

Of the many procedural questions, only two will be addressed here. The first one concerns political and administrative procedures. A point of criticism regarding the measures taken by the Commission and the European Parliament is that their motivation is not the defence of Union values, but the sanctioning of an EU-critical stance. To prove this point, it is said that measures comparable to the Polish ones, when taken by EU-friendly governments, do not elicit any reaction. ${ }^{113}$

\footnotetext{
${ }^{105}$ See Paris (2017), p. 814.

${ }^{106}$ In detail Paris (2017), p. 809 et seq.; Griebel (2014), p. 204; Bäcker (2015), p. 411.

${ }^{107}$ BVerfG, Order of 6 November 2019, 1 BvR 16/13 - Recht auf Vergessen II.

${ }^{108}$ On this discussion, Voßkuhle (2018), pp. 175 and 197; Komárek (2015), p. 75; Thym (2015), p. 56.

${ }^{109}$ Jarass (2016), para. 12.

${ }^{110}$ In this respect, Art. 47 of the Charter transcends Art. 6 ECHR; see also Alber (2016), para. 10. On the validity of art. 47 para. 2 CFR also from an administrative procedural level, Nowak (2011), para. 44.

${ }^{111}$ On the spill-over effects over administrative procedure, cf. Jarass (2016).

${ }^{112}$ Luhmann (1975), pp. 34 et seq., 48 et seq., 116-120; this was also an insight from the Eurozone crisis, Farahat and Krenn (2018), p. 384.

${ }^{113}$ Mendelski (2016).
} 
Hence, the two institutions are accused of misusing their powers for partisan purposes.

As described above (Sect. 2.1), there is room for discretion when deciding whether to initiate a procedure. The accusation is thus to be dealt with under the doctrine on discretion. This doctrine does, however, not limit parliamentary debate: indeed, it is a general principle that parliaments enjoy full freedom of what to debate. ${ }^{114}$ By contrast, the European Commission faces limits. ${ }^{115}$ If it uses an instrument of supervision to sanction an integration-critical general attitude, this would amount to an illegal use of discretion. But to identify such improper use, hard evidence is needed. To date, the Commission's actions seem justified by the extraordinary severity of the situations at hand. ${ }^{116}$

With regard to judicial procedures, the core question is as to whether Member State courts have to refer a case to the CJEU if its subject is a possible systemic deficiency in another Member State. A national court can treat such a deficiency both in the light of the European values, as did the Irish High Court in the Celmer case, ${ }^{117}$ and in the light of the fundamental principles of the national constitution, as in the case 'Identitätskontrolle' of the German Federal Constitutional Court. ${ }^{118}$ The German Court has been much criticised for not having made a preliminary reference. ${ }^{119}$

The general question of a constitutional court's obligation to make such a reference has extensively been discussed. ${ }^{120}$ When it comes to defending values, such a referral to the CJEU is of particular importance for hedging the relationship between the Member States in question. Only a procedure before the CJEU allows for defending European values in a process which respects the very rule of law because it requires a fair procedure. The Member State concerned must be involved. A national court can hardly provide the government of another state with adequate participation. A procedure before the CJEU appears to provide the only orderly way of deciding critical questions in another legal order. There is, moreover, the consideration that 'Europe should speak with one voice'. Even if national courts refer to principles of national identity instead of European values, such national principles can be defended better in the framework of European values. ${ }^{121}$

\footnotetext{
${ }^{114}$ CJEU, Case C-230/81 Luxemburg v. Parliament, ECLI:EU:C:1983:32, para. 39; Bast (2006), para. 28.

${ }^{115}$ Bleckmann (1997), p. 59 et seq.

${ }^{116}$ In detail, Hoffmeister (2015), p. 195 et seq.

${ }^{117}$ IEHC, supra note 16.

${ }^{118}$ BVerfGE 140, 317 - Identitätskontrolle.

${ }^{119}$ On the criticism, Burchardt (2016), p. 527 et seq.; Schönberger (2016), p. 422; Nettesheim (2016), p. 424; Sauer (2016), p. 1134; Classen (2016), p. 304; Nowag (2016), p. 1450 et seq.; Rugge (2016), p. 789.

${ }^{120}$ On this, see Paris (2017).

${ }^{121}$ In detail, Spieker (2020).
} 


\subsection{Material Standards}

All systemic deficiency instruments contain elements describing a particularly problematic situation. Therefore, similar questions of interpretation and application arise. Three questions will be discussed: the interpretive condensing of the requirements (Sect. 3.4.1), the importance of a comprehensive and moreover collective assessment (Sect. 3.4.2) as well as the question of how concrete a violation must be (Sect. 3.4.3).

\subsubsection{Red Lines}

As doctrinal treaties, handbooks and commentaries on the German Basic Law show, many important features of a constitution, even of an entire legal order, can be inferred from principles such as human dignity, rule of law and democracy. To this end, German doctrine considers these principles as 'laws of construction', 122 and even 'optimization requirements' ${ }^{123}$ thereby justifying a scholarship that has something to say on almost any important issue as well as a judiciary that is confident in its sweeping law-making role. There are hints that the Commission is moving towards a similar expansive understanding of EU values, in particular of the rule of law value. ${ }^{124}$ Indeed, the Venice Commission's Rule of Law Checklist with its 53 pages, to which the European Commission refers, almost looks like a detailed manual that provides practitioners with guidance on almost any relevant question. ${ }^{125}$

This cannot be a model for dealing with the values of Article 2 TEU, particularly insofar as they apply to the Member States' legal orders. By using the term value in Article 2 TEU, the Treaty makers imply that its provisions are to be understood as vague and, thus, open. ${ }^{126}$ And this openness is not an authorisation for the Union's institutions to gradually outline an ever more detailed common constitutional law. While Article 2 TEU has become judicially applicable (see above Sect. 3.2), this does not change the fact that it should not develop into a homogeneity clause similar to Article 28 German Basic Law or Article IV Sec. 4 and Articles XIII to XV of the US Constitution. ${ }^{127}$ That would force the constitutional autonomy of the Member

\footnotetext{
${ }^{122}$ Dreier (2015), paras. 5, 8 et seq.; Reimer (2001), p. 26 et seq.

${ }^{123}$ Schulze-Fielitz (2015), para. 44.

${ }^{124}$ Communication from the Commission to the European Parliament, the European Council and the Council, Further strengthening the Rule of Law within the Union State of play and possible next steps, $\operatorname{COM}(2019) 163$ final, p. 1.

${ }^{125}$ European Commission for Democracy Through Law, Rule of Law Checklist, CDL-AD(2016) 007 with its 53 pages just on the rule of law. The European Commission refers to this document as authoritative, see Communication from the Commission, COM(2019) 163 final, p. 8.

${ }^{126}$ Openness is a pivotal point of Schmitt's criticism, Schmitt (2011), pp. 23, 53 et seq.

${ }^{127}$ On this, see Giegerich (2015), p. 499 et seq. For a comparative view, Palermo and Kösserl (2017), p. 321 et seq.
} 
States into a far too narrow corridor, going against European constitutional pluralism.

The 'thickening' of the Article 2 values might endanger European constitutional pluralism. The diversity of Member State constitutions, which is protected by Union law, is enormous. It comprises states with strong, weak or no constitutional courts, markedly different ways of organizing judicial independence, and considerably divergent protections of fundamental rights; it allows for republics and monarchies, parliamentary and semi-presidential systems, strong and weak parliaments, Westminster democracies and consociational democracies, and democracies with strong or weak party structures; and it respects strong or weak societal institutions, unitarian or federal orders as well as anarcho-syndicalist, Catholic, civic, laic, Ottoman, postcolonial, Protestant, socialist and statist constitutional traditions. All these elements play into the various systems of checks and balances, which is why European diversity is particularly pronounced when it comes to this basic feature of any constitutional order. It would be incompatible with this diversity to interpret and apply the values of Article 2 TEU in concrete cases in order to develop them into a kind of DNA of how to set up checks and balances on public authority in the European legal space.

Against this understanding one might argue that the EU Commission has made very detailed requirements on candidate countries, ${ }^{128}$ including, for example, extraditing a former Croat general to the ICTY. ${ }^{129}$ These detailed requirements, never challenged in Court, might be applicable to Member States after accession as well. ${ }^{130}$ Technically, however, these requirements are not linked to Article 2 TEU but to the political Copenhagen criteria. Moreover, candidate countries and Member States have a fundamentally different status, and the accession criteria, finally, are subject to severe criticism themselves. ${ }^{131}$

The constitutional considerations (2) resulted in the conclusion that the instruments for fighting systemic deficiencies serve the cause of ensuring essentials of the European union (Verbund), in particular its self-understanding as a community of values, the core of fundamental rights, and the principle of mutual trust, but nothing more. This explains the values' vagueness as well as the extremely high hurdles in Article 7 TEU. The logic of restraint extends to the entire tool box. Consequently, the values are to be interpreted such as to only prohibit particularly problematic measures, without indicating a 'right way', let alone stipulating the basic organisation of Member State institutions. In this sense, they do not constitute 'laws of construction', but rather 'red lines'. 132

\footnotetext{
${ }^{128}$ See, e.g., European Commission, Communication: Agenda 2000. Vol. I: For a stronger and wider Union, $\operatorname{COM(2000)} 97$ final, p. 42.

${ }^{129}$ For a detailed analysis, see Rötting (2009), pp. 117 et seq.

${ }^{130} \mathrm{On}$ the Copenhagen criteria as guidelines for the application of Article 2 TEU, see Hillion (2016), p. 66.

${ }^{131}$ Kochenov (2008), p. 311; Kosar et al. (2019), 443 et seq.

${ }^{132}$ In detail, von Bogdandy et al. (2018), p. 963.
} 
The CJEU's decisions can be understood in this light. The logic of red lines explains a reasoning which may appear rather 'thin' and therefore little convincing at first sight. In most cases, the pertinent value is illustrated only in a general manner, with reference to principles; $;{ }^{133}$ but there is only little interpretive development in view of the matter concerned. The central aspect is what cannot be tolerated. While the lack of interpretive development limits the persuasive power of the judgment, it is by this abstaining that interpretative standards which could considerably limit the Member States' constitutional autonomy can be avoided. ${ }^{134}$

In the seminal Aranyosi e Căldăraru judgment, the Court refers only to absolute rights, especially to the prohibition of inhuman treatment, ${ }^{135}$ i.e. to norms which are part of the core of European self-understanding. ${ }^{136}$ This likewise holds true for the essence of non-absolute rights: In the L.M. (Deficiencies in the system of justice) judgment, the CJEU states that the newly established disciplinary chamber is problematic, given its appearance as an instrument to cow judges. ${ }^{137}$ The judgment outlines further 'red lines' by referring to the qualifications on Poland made in the Commission proposal under Article 7 TEU. Of course, the Court does not treat the proposal as a source of law. Nevertheless, the 'information (...) is particularly relevant' and thus serves to assess the Polish measures. ${ }^{138}$ This Commission proposal concretely articulates which measures are incompatible with the values and must therefore be revoked for crossing 'red lines'.

This logic of 'red lines' provides indications on how to rebut the presumption, founded in Article 49 TEU, that a Member State complies with European values. Such a doctrine, however, is fundamentally different from a conventional constitutional doctrine of principles that aims at developing from principles an 'overall structure' for the entire legal order. ${ }^{139}$ It would rather have to follow the logic of 'negative dialectics', which is characterised by the very fact of not specifying what the ideal situation should look like, but rather what must not be.

\footnotetext{
${ }^{133} \mathrm{Cf}$., in particular, Proposal for a Council Decision on the determination of a clear risk of a serious breach by the Republic of Poland of the rule of law (COM(2017) 835 final), para. 6 et seq., and CJEU, Minister for Justice and Equality, supra note 37, paras. 62-67. At the same time, it should be underlined that the L.M. judgment provides much more justification than the similarly seminal CJEU, Ruiz Zambrano, supra note 36.

${ }^{134}$ On this way of forming standards, Lepsius (2011), p. 182 et seq.; von Bogdandy and Venzke (2014), p. 254 et seq.

${ }^{135} \mathrm{CJEU}$, Aranyosi and Căldăraru, supra note 74.

${ }^{136}$ Grabenwarter (2017), p. 3052.

${ }^{137} \mathrm{CJEU}$, Minister for Justice and Equality, supra note 37, para. 67.

${ }^{138} I d$., para. 61.

${ }^{139}$ Schuppert and Bumke (2000), pp. 28, 39; on 'guiding principles', Volkmann (2008), p. 67 et seq.
} 


\subsubsection{The Comprehensive and Collective Assessment}

Most institutions base the determination that a value has been violated on a comprehensive assessment. The analysis of the Commission's and the CJEU's pertinent decisions shows that they consider a series of facts to this end, often described in detail, in the light of principles that remain abstract. ${ }^{140}$ Such an application, which essentially consists in a comprehensive assessment of developments, events, measures and political statements, is an exercise in discretion and hence inevitably evaluative, and in that sense political. This easily gives rise to the accusation that the decisions are biased or motivated by illicit considerations. ${ }^{141}$

Yet, this practice of assessing is justified by three aspects. Firstly, it is the inevitable consequence of the restrained interpretation, which in turn is justified by the constitutional considerations described in the preceding passage. Secondly, the practice responds to the specific problems of legally capturing authoritarian tendencies. Thirdly, it must be taken into account that the comprehensive assessment is often based on similar perceptions of other institutions and thus takes place collectively (Einschätzungsverbund).

The central role of a comprehensive assessment is justified by the very nature of systemic deficiencies. Usually, the law is applied to a single action or measure. This mode fails with regard to authoritarian developments, as in most cases only a series of actions and measures in their entirety will reach the critical threshold. The actions and measures, taken individually, can often be plausibly justified. ${ }^{142}$ The Polish government defends its judicial reforms by means of a legal comparison with 'unsuspicious' countries. ${ }^{143}$ In order to establish a 'clear risk of a serious breach' of Article 2 TEU, a comprehensive view of all measures taken by the Polish government with regard to the judiciary is needed, with due consideration of the general political and social conditions of the country. One needs to assess the actions against the judiciary in the context of the actions against other controlling institutions, mainly the parliamentary opposition, the media, science, and NGOs. ${ }^{144}$ This contextual approach has been confirmed by the Court of Justice stated in A.K., which

\footnotetext{
${ }^{140}$ Proposal for a Council decision on the determination of a clear risk of a serious breach by the Republic of Poland of the rule of law (COM(2017) 835 final), paras. 109, 173; CJEU, Minister for Justice and Equality, supra note 37, para. 68; CJEU, Joined Cases C-585/18, C-624/18 and C-625/ 18 A.K. (Indépendance de la chambre disciplinaire de la Cour supreme), ECLI:EU:C:2019:982, para. $127,134,152$.

${ }^{141}$ See above, Sect. 3.3.

${ }^{142}$ Scheppele (2016), p. 105. Nevertheless, some Polish measures against the country's own constitutional court appear as rather clear cases, cf. Iustitia (2018), Gersdorf (2018); Venice Commission, Opinion on Amendments to the Act of 25 June 2015 on the Constitutional Tribunal of Poland, Opinion no. 833/2015, CDL-AD(2016)001, paras. 126, 137, 138.

${ }^{143}$ Chancellery of the Prime Minister of Poland (2018).

${ }^{144}$ This logic of the comprehensive assessment is by no means restricted to the values. The process of establishing a systemic deficiency in the banking sector is similar, cf. Regulation (EU) on European Union macro-prudential oversight of the financial system and establishing a European Systemic Risk Board (2010) OJ L331/1.
} 
dealt with the independence of the Polish Supreme Court's Disciplinary Chamber. ${ }^{145}$

A third aspect contributing to the legitimacy of a comprehensive assessment lies in basing it on concurrent evaluations of other independent institutions, institutions with a recognized authority in questions of values. The regular application takes place in an Einschätzungsverbund, i.e., the comprehensive assessment of all circumstances must be widely shared. The more institutions perceive a substantial problem, the stronger the evidence for a systemic deficiency.

It is noteworthy that when it comes to systemic deficiencies, interpretation and application are not presented as being autonomous, but as part of a collective assessment involving many institutions of various legal orders. The Commission and the CJEU, but also many other institutions, recur to other authoritative sources when dealing with such questions, in particular to judgments of the ECtHR and opinions of the Venice Commission. ${ }^{146}$ Evaluations of international bodies as well as civic organisations are also significant. ${ }^{147}$ In the light of the cherished autonomy of Union law, it appears especially noteworthy that the Commission and the Court give much weight to evaluations under the national legal order concerned; such evaluations even enjoy particular relevance. In the Polish case, an important point is that authoritative Polish voices consider the governing majority's reforms as deeply unconstitutional. ${ }^{148}$ Thus, a situation or measure is more likely to qualify as systemically deficient the more institutions of the various legal orders share this qualification.

Such a comprehensive assessment is also important in other respects. One need only think of the accusation that the Union itself does not meet the requirements that it demands Poland to fulfil. ${ }^{149}$ Certainly, the possibility of the CJEU's judges to be re-elected does not meet the highest standards of judicial independence. However, in pertinent research, it is undisputed that the CJEU is an independent court. ${ }^{150}$

\subsubsection{On the Concreteness of the Risk}

The political institutions usually assess a general situation and decide whether there is a general risk for the values, for example by the Polish remodelling of its judiciary

\footnotetext{
${ }^{145} \mathrm{CJEU}$, A.K. (Indépendance de la chambre disciplinaire de la Cour supreme), ECLI:EU: C:2019:982, paras. 142, 152.

${ }^{146} \mathrm{Cf}$. Proposal for a Council decision on the determination of a clear risk of a serious breach by the Republic of Poland of the rule of law (COM(2017) 835 final), paras. 18, 32, 95, 116 et seq.; CJEU, Case C-404/15 Aranyosi and Căldăraru, supra note 74, para. 90; Opinion of AG Tanchev in CJEU, Minister for Justice and Equality, supra note 37, para. 10.

${ }^{147}$ Proposal for a Council decision on the determination of a clear risk of a serious breach by the Republic of Poland of the rule of law (COM(2017) 835 final), paras. 33, 63, 76, 80, 82.

${ }^{148} I d$., paras. 19, 21, 29, 81, 83, 86; cf. in particular Iustitia (2018), Gersdorf (2018).

${ }^{149} \mathrm{Cf}$. Weiler (2016).

${ }^{150}$ Krenn (2018), p. 2024.
} 
since 2015. For the courts, the question arises whether such abstract risk is enough for a judicial decision, or whether a risk would have to materialise concretely in the case at hand in order to be relevant. The L.M. case concerned the question of whether an Irish court must surrender an individual to Poland under a European arrest warrant notwithstanding the general remodelling of the Polish judiciary. The CJEU answered that the national court must verify in a two-step procedure (1) whether there is a systemic deficiency in Poland and (2) if there are 'substantial grounds for believing that the individual concerned will run a real risk of breach of his fundamental right to an independent tribunal and, therefore, of the essence of his fundamental right to a fair trial'. ${ }^{151}$

This two-step review helps to distinguish the legal procedure from the political one under Article 7 TEU. It thus contributes to justifying the CJEU's decision. ${ }^{152}$ However, it meets with considerable doubts. Since the measures of the Polish government undermine the independence of the entire Polish judiciary, any case runs the risk of being decided by a compromised judge at some point. Moreover, the CJEU's stipulation that Member State judges must review the independence of their Polish colleagues ${ }^{153}$ appears hardly feasible. ${ }^{154}$ At least there is a reversal of the burden of proof: in case of a (general) systemic deficiency, it is the Member State in question to give evidence that there is no concrete risk for the individual concerned. ${ }^{155}$

\subsection{Control}

The last building block is the issue of legal protection. It deals with the question of whether and how the instruments' lawfulness as well as the lawfulness of their use can be judicially reviewed. Such review is a core aspect of the European rule of law: the control of public authority by independent and impartial courts is sometimes even considered the crowning element of the rule of law. ${ }^{156}$ Article 269 TFEU therefore describes an exception that is to be interpreted narrowly.

Self-evident as this principle might appear, its application is problematic with regard to instruments that do not yield a legal consequence; the protection by the CJEU has long been fragmentary and uncertain in this respect. It appears anything but certain that a Member State can take legal action against a recommendation of the Commission in the framework of the rule of law procedure or against a

\footnotetext{
${ }^{151}$ CJEU, Minister for Justice and Equality, supra note 37, para. 75. On this, von Bogdandy et al. (2018), p. 983.

${ }^{152}$ Cf. above, Sect. 3.2.

${ }^{153} \mathrm{CJEU}$, Minister for Justice and Equality, supra note 37, para. 77 et seq.

${ }^{154}$ Wendel (2019), p. 111; Krajewski (2018), p. 792; Bárd and van Ballegooij (2018), p. 353.

${ }^{155} \mathrm{CJEU}$, Minister for Justice and Equality, supra note 37, para. 78.

${ }^{156}$ Cf. CJEU, Case C-294/83 Les Verts v. Parliament, ECLI:EU:C:1986:166.
} 
classification in the Justice Score Board that damages its reputation. Yet, the more recent case-law of the CJEU is expanding judicial control with regard to such measures. ${ }^{157}$ This should make control possible at least when a recommendation of the Commission results in indirect legal consequences, e.g., when it provides a basis for assuming a systemic deficiency. ${ }^{158}$ However, there is need for more legal protection, e.g., against recommendations damaging a Member State's reputation.

Another challenge is how to coordinate judicial control between the various legal orders of the European legal space. This leads again to Article 267 TFEU. There is an urgent need for such coordination when defending European values or their equivalents in the national constitutions. The coordination and control of national courts is primarily a task of the CJEU. Yet this does not imply that the CJEU itself is beyond control: it remains subject to the general mechanisms, which assume particular importance with regard to this explosive question. In this respect, the multilevel cooperation of the European courts might find here its finest hour. ${ }^{159}$

\section{Towards a Tyranny of Values?}

To many people, the European institutions appear distant and foreign. If they urge or even try to force democratically elected governments to revise important political projects, invoking European values, they run the risk of being rejected as selfimportant, arbitrary and illegitimate actors. Just thumping on the lawfulness of such actions is hardly an appropriate response to accusations of moving towards a tyranny of values. 'Being right' is not sufficient. In order to credibly defend European values, one must make use of fair procedures to convincingly show a broad European public what the values require, why they have been violated and what needs to be done. Defending European values in such a way will not appear as potentially tyrannical, but rather what most European citizens expect the Union to do. ${ }^{160}$

Acknowledgments Translated from German by Annika Müller. I would like to thank the Dienstagsrunde, in particular Dr. Laura Hering, Giacomo Rugge, Matthias Schmidt, and Dimitri Spieker, for their valuable critique and support. Unless stated otherwise, all quotes translated from German were translated by the author.

\footnotetext{
${ }^{157}$ CJEU, Case C-16/16 P Belgium v. Commission, ECLI:EU:C:2018:79, para. 44; Case C-258/14 Florescu and Others, ECLI:EU:C:2017:448, para. 30; Case C-207/01 Altair Chimica, ECLI:EU: C:2003:451, para. 41; Opinion of Advocate General Cruz Villalón in CJEU, Gauweiler and Others, supra note 18, para. 27 et seq.; Gundel (2018), p. 593; Schmidt-Aßmann (2013), p. 103.

${ }^{158}$ In detail, see above, Sect. 3.4.1.

${ }^{159}$ Voßkuhle (2018), Huber (2017), p. 389.

${ }^{160}$ Special Eurobarometer 489 rule of law, <data.europa.eu/euodp/en/data/dataset/S2235_91_3_ 489_ENG>.
} 


\section{References}

Ackerman B (1991) We the people, Volume 1: foundations. Belknap Press of Harvard University Press, Cambridge

Ackerman R, Desierto D, Volosin N (2011) Hyper-Presidentialism: separation of powers without checks and balances in Argentina and Philippines. Berkeley J Int Law 20:246-271

Ahtisaari M, Frowein J, Oreja M (2000) Report on the commitment of the Austrian Government to the common European values, adopted in Paris on 8 September 2000

Alber S (2016) Art. 47. In: Stern K, Sachs M (eds) Europäische Grundrechte-Charta. C.H. Beck, München, pp 699-730

Bachmann K (2018) Zur Entwicklung der polnischen Demokratie. Aus Politik und Zeitgeschichte 10-11:9-14

Bäcker M (2015) Das Grundgesetz als Implementationsgarant der Unionsgrundrechte. EuR 50:389-414

Bárd P, van Ballegooij W (2018) Judicial independence as a precondition for mutual trust? The CJEU in Minister for Justice and Equality v. LM. New J Eur Crim Law 9

Bast J (2006) Grundbegriffe der Handlungsformen der EU. Springer, Berlin

Bast J (2018) Art. 5 EUV. In: Grabitz E, Hilf M, Nettesheim M (eds) Das Recht der Europäischen Union. C.H. Beck, München

Binder C (2013) Die Grenzen der Vertragstreue im Völkerrecht. Springer, Berlin

Blagoev B (2011) Expulsion of a Member State from the EU after Lisbon: political threat or legal reality? Tilburg Law Rev 16:191-237

Blauberger M (2016) Europäischer Schutz gegen nationale Demokratiedefizite? Leviathan 44:280-302

Bleckmann A (1997) Ermessensfehlerlehre: Völker- und Europarecht, vergleichendes Verwaltungsrecht. Heymanns, Köln

Böckenförde EW (1990) Grundrechte als Grundsatznormen: Zur gegenwärtigen Lage der Grundrechtsdogmatik. Der Staat 29:1-31

Brauneck J (2019) Gefährdung des EU-Haushalts durch rechtsstaatliche Mängel in den Mitgliedstaaten? EuR 54:37-61

Burchardt D (2016) Die Ausübung der Identitätskontrolle durch das Bundesverfassungsgericht. ZaöRV 76:527-551

Canor I (2013) My brother's keeper? Horizontal solange: "An ever closer distrust among the peoples of Europe". Common Mark Law Rev 50:383-422

Carp R (2014) The struggle for the rule of law in Romania as an EU Member State: the role of the cooperation and verification mechanism. Utrecht Law Rev 10(1):16

Cassese S (2017) The 'constitutional traditions common to the Member States' of the European Union. Rivista Trimestrale di Diritto Pubblico:939-948

Chancellery of the Prime Minister of Poland (2018) White Paper on the Reform of the Polish Judiciary. https://www.premier.gov.pl/files/files/white_paper_en_full.pdf

Classen CD (2016) $\mathrm{Zu}$ wenig, zu fundamentalistisch - zur grundrechtlichen Kontrolle "unionsrechtlich determinierter" nationaler Hoheitsakte. EuR 51:304-312

Closa C, Kochenov D (eds) (2016) Reinforcing the rule of law oversight in the European Union. Cambridge University Press, Cambridge

Closa C, Kochenov D, Weiler JHH (2014) Reinforcing rule of law oversight in the European Union. EUI Working Paper RSCAS 2014/25

Crawford JR (2013) Overview of part three of the articles on state responsibility. In: Crawford JR, Pellet A, Olleson S (eds) The law of international state responsibility. Oxford University Press, Oxford, pp 931-940

Croon-Gestefeld J (2017) Reverse Solange - Union Citizenship as a Detour on the Route to European Rights Protection Against National Infringements. In: Kochenov D (ed) EU citizenship and federalism: the role of rights. Cambridge University Press, Cambridge, pp 665-683 
Dori A (2015) The EU Justice Scoreboard - Judicial Evaluation as a new Governance Tool. MPILux Working Paper 2. http://www.mpi.lu/fileadmin/mpi/medien/persons/Dori_Adriani/ The_EU_Justice_Scoreboard_-_Judicial_Evaluation_as_a_New_Governance_Tool.pdf

Dreier H (2015) Art. 20 (Einführung). In: Dreier H (ed) Grundgesetz-Kommentar, 3rd edn. Mohr Siebeck, Tübingen, pp 1-10

Dyzenhaus D (2012) State of emergency. In: Rosenfeld M, Sajó A (eds) The Oxford handbook of comparative constitutional law. Oxford University Press, Oxford, pp 442-460

Farahat A, Krenn C (2018) Der Europäische Gerichtshof in der Eurokrise: eine konflikttheoretische Perspektive. Der Staat 57:357-385

Franzius C (2018) Der Kampf um Demokratie in Polen und Ungarn. DÖV 71:381-388

García Morales MJ (2018) Federal execution, Article 155 of the Spanish Constitution and the crisis in Catalonia. ZöR 73:791-830

Gersdorf M (2018) Opinion on the White Paper on the Reform of the Polish judiciary. http://www. sn.pl/aktualnosci/SiteAssets/Lists/Wydarzenia/EditForm/Supreme\%20Court\%20-\%20Opinion $\% 20$ on $\% 20$ the $\% 20$ white $\% 20$ paper\%20on $\% 20$ the $\% 20$ Reform $\% 20$ of $\% 20$ the $\% 20$ Polish $\%$ 20Judiciary.pdf

Giegerich T (2015) Verfassungshomogenität, Verfassungsautonomie und Verfassungsaufsicht in der EU: Zum 'neuen Rechtsstaatsmechanismus' der Europäischen Kommission. In: Calliess C (ed) Herausforderungen an Staat und Verfassung: Liber Amicorum für Torsten Stein zum 70. Geburtstag, Nomos, Baden-Baden, pp 499-542

Grabenwarter C (2017) Konventionswidrigkeit der Auslieferung bei drohender Todesstrafe - Fall Soering. NJW 70:3052

Grabenwarter C (2018) Die Herausbildung europäischer Verfassungsstandards in der VenedigKommission. JöR 66:21-41

Graziadei M, de Caria R (2017) The "Constitutional Traditions Common to the Member States" in the case-law of the European Court of Justice. Judicial Dialogue at its Finest. Rivista Trimestrale di Diritto Pubblico:949-971

Griebel J (2014) Europäische Grundrechte als Prüfungsmaßstab der Verfassungsbeschwerde. DVB1 2014:204-211

Gundel J (2018) Rechtsschutz gegen Empfehlungen der EU-Kommission? Anmerkung zum Urteil des EuGH (GK) v. 20.2.2018, Rs. C-16/16 P (Belgien/Kommission). EuR 53:593-605

Habermas J (1992) Faktizität und Geltung. Suhrkamp, Berlin

Halmai G (2017) The early retirement age of the Hungarian Judges. In: Nicola F, Davies B (eds) EU law stories. Cambridge University Press, Cambridge, pp 471-488

Halmai G (2018a) Illiberal constitutionalism? The Hungarian Constitution in a European perspective. In: Kadelbach S (ed) Verfassungskrisen in der Europäischen Union. Nomos, Baden-Baden, pp 85-104

Halmai G (2018b) The possibility and desirability of rule of law conditionality. Hague J Rule Law 11:171-188

Hartmann N (1926) Ethik. De Gruyter, Berlin

Henderson J (2018) Russia's recent dealings with the Council of Europe and European Court of Human Rights. Eur Public Law 24:393-402

Hilf M, Schorkopf F (2017) Art. 2 EUV. In: Grabitz E, Hilf M, Nettesheim M (eds) Das Recht der Europäischen Union. C.H. Beck, München

Hillion C (2016) Overseeing the rule of law in the EU: legal mandate and means. In: Closa C, Kochenov D (eds) Reinforcing the rule of law oversight in the European Union. Cambridge University Press, Cambridge, pp 59-81

Hirsch Ballin E (2016) Mutual trust: the virtue of reciprocity - strengthening the acceptance of the rule of law through peer review. In: Closa C, Kochenov D (eds) Reinforcing the rule of law oversight in the European Union. Cambridge University Press, Cambridge, pp 133-146

Hoffmeister F (2015) Enforcing the EU Charter of Fundamental Rights in Member States: how far are Rome, Budapest and Bucharest from Brussels. In: von Bogdandy A, Sonnevend P (eds) 
Constitutional crisis in the European constitutional area. C.H. Beck/Hart/Nomos, Baden-Baden, pp 195-233

Huber PM (2017) Europäische Verfassungs- und Rechtsstaatlichkeit in Bedrängnis. Der Staat 56:389-414

International Law Association (2018) Final Report on Aggression and the Use of Force, Sydney. http://www.ila-hq.org/images/ILA/DraftReports/DraftReport_UseOfForce.pdf

Iustitia (2018) Response to the White Paper Compendium on the reforms of the Polish justice system. Presented by the Government of the Republic of Poland to the European Commission. http://www.statewatch.org/news/2018/mar/pl-judges-association-response-judiciary-reform-318.pdf

Jakab A, Kochenov D (eds) (2017) Protecting European values. Oxford University Press, Oxford

Jakab A, Lorincz VO (2017) International Indices as Models for the Rule of Law Scoreboard of the European Union: Methodological Issues. MPIL Research Paper No. 2017-21. https://papers. ssrn.com/sol3/papers.cfm?abstract_id $=3032501$

Janse R (2019) Is the European Commission a credible guardian of the values?: A revisionist account of the Copenhagen political criteria during the Big Bang enlargement. Int J Const Law 17:43-65

Jarass H (2016) Art. 47 GRCh. In: Jarass H (ed) Charta der Grundrechte der EU, 3rd edn. C.H. Beck, München, pp 405-427

Kailitz S, Köllner P (2012) Zur Autokratieforschung der Gegenwart: Klassifikatorische Vorschläge, theoretische Ansätze und analytische Dimensionen. Politische Vierteljahresschrift 47:9-41

Kochenov D (2008) EU enlargement and the failure of conditionality: pre-accession conditionality in the fields of democracy and the rule of law. Wolters-Kluwer, Austin

Kochenov D (2013) On policing Article 2 TEU compliance - Reverse Solange and systemic infringements analyzed. Polish Yearb Int Law 33:145-170

Kochenov D (2015) Biting intergouvernmentalism: the case for the reinvention of Article 259 TFEU to make it a viable rule of law enforcement tool. Hague J Rule Law 7:153-174

Kochenov D, Pech L (2016) Better late than never? On the European Commission's rule of law framework and its first activation. J Common Mark Stud 54:1062-1074

Kochenov D, Pech L (2018) Monitoring and enforcement of the rule of law in the EU: rhetoric and reality. EuConst 11:512-540

Komárek J (2015) Why National Constitutional Courts should not embrace EU fundamental rights. In: de Vries S, Bernitz U, Weatherill S (eds) The EU Charter of fundamental rights as binding instruments. Hart, Oxford, pp 75-92

Kosar D, Baros J, Dufek P (2019) The twin challenges to separation of powers in Central Europe: technocratic governance and populism. EuConst 15:427-461

Krajewski M (2018) Who is afraid of the European Council? The Court of Justice's cautious approach to independence of domestic judges. EuConst 14:792-813

Krenn C (2018) Self-Government at the Court of Justice of the European Union: a bedrock for institutional success. Germ Law J 19:2007-2030

Lacchi C (2015) Review by constitutional courts of the obligation of National Courts of last instance to refer a preliminary question to the Court of Justice of the EU. Germ Law J 16:1663-1700

Lachmayer K (2017) Questioning the basic values - Austria and Jörg Haider. In: Jakab A, Kochenov D (eds) The enforcement of EU law and values. Oxford University Press, Oxford

Lauth H, Sehring J (2009) Putting Deficient Rechtsstaat on the Research Agenda: reflections on diminished subtypes. Comp Sociol 8:165-201

Łazowski A (2012) European Union do not worry, Croatia is behind you: a commentary on the Seventh Accession Treaty. Croatian Yearb Eur Law Policy 8:1-39

Lenaerts K (2017) La vie après l'avis: exploring the principle of mutual (yet not blind) trust. Common Mark Law Rev 54:805-840

Lepsius O (2011) Die maßstabsetzende Gewalt. In: Jestaedt M, Lepsius O, Möllers C, Schönberger C (eds) Das entgrenzte Gericht. Suhrkamp, Berlin, pp 159-280 
Levits E (2018) Die Europäische Union als Wertegemeinschaft. In: Jaeger T (ed) Europa 4.0. Jan Sramek Verlag KG, Wien, pp 239-270

Luhmann N (1975) Legitimation durch Verfahren, 2nd edn. Suhrkamp, Berlin

Luhmann N (1993) Gibt es in unserer Gesellschaft noch unverzichtbare Normen? C.F. Müller, Heidelberg

Mälksoo M (2009) The memory politics of becoming European: the East European subalterns and the collective memory of Europe. Eur J Int Relat 15:653-680

Martenczuk B (2018) Art. 7 EUV und der Rechtsstaatsrahmen als Instrument der Wahrung der Grundwerte der Union. In: Kadelbach S (ed) Verfassungskrisen in der Europäischen Union. Nomos, Baden-Baden

Mendelski M (2016) Das europäische Evaluierungsdefizit der Rechtsstaatlichkeit. Leviathan 44:366-398

Mengozzi P (2015) A European Partnership of Courts. Judicial Dialogue between the EU Court of Justice and National Constitutional Courts. Il Diritto dell'Unione Europea 701-720

Merkel W (2013) Vergleich politischer Systeme: Demokratien und Autokratien. In: Schmidt MG, Wolf F, Wurster S (eds) Studienbuch Politikwissenschaft. Springer, Berlin, pp 207-236

Möllers C, Schneider L (2018) Demokratiesicherung in der Europäischen Union. Mohr Siebeck, Tübingen

Mosler H (1968) Begriff und Gegenstand des Europarechts. ZaöRV 28:481-502

Müller JW (2015) Should the EU protect democracy and the rule of law inside Member States? Eur Law J 21:141-160

Muszyński M (2018) Polski Trybunał w unijnej rzeczywistości. Rzeczpospolita. https://www.rp.pl/ Opinie/303229983-Polski-Trybunal-w-unijnej-rzeczywistosci\%2D\%2D-Mariusz-Muszynskio-mocy-wyrokow-TSUE-w-Polsce.html

Nergelius J (2015) The role of the Venice Commission in maintaining the rule of law in Hungary and in Romania. In: von Bogdandy A, Sonnevend P (eds) Constitutional crisis in the European constitutional area. C.H. Beck/Hart/Nomos, Baden-Baden, pp 291-308

Nettesheim M (2009) Ein Individualrecht auf Staatlichkeit? Die Lissabon-Entscheidung des BVerfG. NJW 62:2867-2869

Nettesheim M (2016) Anmerkung. JZ 71:424-428

Nettesheim M (2018) Art. 288 AEUV. In: Grabitz E, Hilf M, Nettesheim M (eds) Das Recht der Europäischen Union. C.H. Beck, München

Nicolisi S (2015) The Contribution of the Court of Justice to the codification of the founding values of the European Union. Revista de Derecho Comunitario Europeo 51:613-643

Nowag J (2016) EU law, constitutional identity, and human dignity: A toxic mix? Bundesverfassungsgericht: Mr R. Common Mark Law Rev 53:1441-1453

Nowak C (2011) Europäisches Verwaltungsrecht und Grundrechte. In: Terhechte JP (ed) Verwaltungsrecht der Europäischen Union. Nomos, Baden-Baden, pp 519-584

Palermo F, Kösserl K (2017) Comparative Federalism. Hart, Oxford

Paris D (2017) Constitutional courts as European Union courts: the current and potential use of EU law as a yardstick for constitutional review. Maastricht J Eur Comp Law 24:792-821

Regan E (2018) The role of the principles of mutual trust and mutual recognition in EU law. Il Diritto dell'Unione Europea 231-248

Reimer F (2001) Verfassungsprinzipien. Duncker \& Humblot, Berlin

Rötting M (2009) Das verfassungsrechtliche Beitrittsverfahren zur Europäischen Union. Springer, Berlin

Ruffert M (2016) Art. 7 EUV. In: Calliess C, Ruffert M (eds) EUV/AEUV, 5th edn, pp 166-174

Rugge G (2016) Bundesverfassungsgericht e Corte di Giustizia dell'UE: quale futuro per il dialogo sul rispetto dell'identità nazionale?. Il Diritto dell'Unione Europea pp 789-812

Russo AM (2014) La cittadinanza 'sostanziale' dell'UE alla luce della proposta del gruppo di Heidelberg: verso una 'reverse Solange'?. federalismi.it

Sadurski W (2019) Poland's constitutional breakdown. Oxford University Press, Oxford 
Sauer H (2016) "Solange" geht in Altersteilzeit - Der unbedingte Vorrang der Menschenwürde vor dem Unionsrecht. NJW 69:1134-1138

Scheppele K (2016) Enforcing the basic principles of EU law through systemic infringement actions. In: Closa C, Kochenov D (eds) Reinforcing the rule of law oversight in the European Union. Cambridge University Press, Cambridge, pp 105-132

Schmidt M, Bogdanowicz P (2018) The infringement procedure in the rule of law crisis: how to make effective use of Article 258 TFEU. Common Mark Law Rev 55:1061-1100

Schmidt-Aßmann E (2013) Verwaltungsrechtliche Dogmatik. Mohr Siebeck, Tübingen

Schmitt C (2011) Die Tyrannei der Werte. 3rd corrected edn, with an afterword by Christoph Schönberger. Duncker \& Humblot, Berlin

Schönberger C (2016) Anmerkung. JZ 71:422-424

Schorkopf F (2002) Die Maßnahmen der XIV EU-Mitgliedstaaten gegen Österreich. Springer, Berlin

Schorkopf F (2016) Wertesicherung in der Europäischen Union. Prävention, Quarantäne und Aufsicht als Bausteine eines Rechts der Verfassungskrise? EuR 51:147-163

Schulze-Fielitz H (2015) Art. 20 Abs. 2 Satz 2 und Abs. 3 (Rechtsstaat). In: Dreier H (ed) Grundgesetz-Kommentar, Band 2, 3rd edn 2015. Mohr Siebeck, Tübingen, pp 186-291

Schuppert GF, Bumke C (2000) Die Konstitutionalisierung der Rechtsordnung. Nomos, BadenBaden

Senden L (2004) Soft law in European community law. Hart, Oxford

Spieker LD (2019) Breathing life into the Union's common values: on the Judicial Application of Article 2 TEU in the EU value crisis. Germ Law J 20:1182-1213

Spieker LD (2020) Framing and managing constitutional identity conflicts: how to stabilize the modus vivendi between the Court of Justice and national constitutional courts. Common Mark Law Rev 20:361-398

Stein T (1998) Die rechtlichen Reaktionsmöglichkeiten der Europäischen Union bei schwerwiegender und anhaltender Verletzung der demokratischen und rechtsstaatlichen Grundsätze in einem Mitgliedstaat. In: Götz V, Selmer P, Wolfrum R (eds) Liber amicorum Günther Jaenicke. Springer, Berlin, pp 871-898

Steinbeis M (2018) The Deed, not the Doer. Verfassungsblog. https://verfassungsblog.de/the-deednot-the-doer/

Steinbeis M, Kemmerer A, Möllers C (eds) (2015) Gebändigte Macht: Verfassung im europäischen Nationalstaat. Nomos, Baden-Baden

Steininger S (2018) Managing the Backlash? The PACE and the Question of Participation Rights for Russia. Verfassungsblog. https://verfassungsblog.de/managing-the-backlash-the-pace-andthe-question-of-participation-rights-for-russia/

Thym D (2015) Vereinigt die Grundrechte! JZ 70:53-63

Toggenburg GN (2013) Was soll die EU können dürfen, um die EU-Verfassungswerte und die Rechtsstaatlichkeit der Mitgliedstaaten zu schützen? Ausblick auf eine neue Europäische Rechtsstaatshygiene. ÖGfE Policy Brief. https://oegfe.at/wordpress/wp-content/uploads/2015/ 07/OEGfE_Policy_Brief-2013.10.pdf

Tuori K (2016) From Copenhagen to Venice. In: Closa C, Kochenov D (eds) Reinforcing the rule of law oversight in the European Union. Cambridge University Press, Cambridge, pp 225-246

Uerpmann-Wittzack R (2009) The constitutional role of international law. In: von Bogdandy A, Bast J (eds) Principles of European constitutional law, 2nd rev. edn. Hart/C.H. Beck/Nomos, Oxford/München, pp 131-167

Vachudova MA (2016) Why improve EU oversight of rule of law. In: Closa C, Kochenov D (eds) Reinforcing the rule of law oversight in the European Union. Cambridge University Press, Cambridge, pp 270-289

van Middelaar L (2016) Vom Kontinent zur Union. Gegenwart und Geschichte des vereinten Europa. Suhrkamp, Berlin

Volkmann U (2008) Verfassungsrecht zwischen normativem Anspruch und politischer Wirklichkeit. VVDStRL 67:57-93 
Volkmann U (2018) Wertedämmerung. Merkur 72:5-17

von Bogdandy A (2008) The European Union as situation, executive, and promoter of the international law of cultural diversity - elements of a beautiful friendship. Eur J Int Law 19 (2):241-275

von Bogdandy A (2010) Constitutional principles. In: von Bogdandy A, Bast J (eds) Principles of European constitutional law. Modern studies in European law. Hart, Oxford, pp 11-52

von Bogdandy A (2014) Common principles for a plurality of orders: a study on public authority in the European legal area. I•CON 12:980-1007

von Bogdandy A (2016) European law beyond 'Ever Closer Union' repositioning the concept, its thrust and the EJC's comparative methodology. Eur Law J 22(4):519-538

von Bogdandy A (2018) Ways to frame the European rule of law: Rechtsgemeinschaft, trust, revolution, and Kantian Peace. EuConst 14:657-699

von Bogdandy A, Sonnevend P (eds) (2015) Constitutional crisis in the European constitutional area. C.H. Beck/Hart/Nomos, Oxford/Portland

von Bogdandy A, Spieker D (2019) Countering the Judicial Silencing of critics: Article 2 TEU values, reverse Solange, and the responsibilities of National Judges. EuConst 15:391-426

von Bogdandy A, Venzke I (2014) In wessen Namen? Internationale Gerichte in Zeiten globalen Regierens. Suhrkamp, Berlin

von Bogdandy A, Kottmann M, Antpöhler C, Dickschen J, Hentrei S, Smrkol M (2012) Reverse Solange - protecting the essence of fundamental rights against EU Member States. Common Mark Law Rev 49:489-519

von Bogdandy A, Kottmann M, Antpöhler C, Dickschen J, Hentrei S, Smrkol M (2015) A European response to domestic constitutional crisis: advancing the Reverse-Solange Doctrine. In: von Bogdandy A, Sonnevend P (eds) Constitutional crisis in the European constitutional area. Theory law and politics in Hungary and Romania. C.H. Beck/Hart/Nomos, Oxford/ Portland, pp 248-267

von Bogdandy A, Bogdanovic P, Canor I, Schmidt M, Taborowski M (2018) Guest editorial: a potential constitutional moment for the European rule of law - the importance of red lines. Common Mark Law Rev 55:983-995

Voßkuhle A (2018) Die Idee der Europäischen Wertegemeinschaft. Verlag der Buchhandlung Klaus Bittner, Köln

Weiler JHH (2016) Epilogue: living in a glass house: Europe, democracy and the rule of law. In: Closa C, Kochenov D (eds) Reinforcing the rule of law oversight in the European Union. Cambridge University Press, Cambridge, pp 313-326

Wendel M (2019) Rechtsstaatlichkeitsaufsicht und gegenseitiges Vertrauen. EuR 54:111-132

Wittinger M (2005) Der Europarat: Die Entwicklung seines Rechts und der "europäischen Verfassungswerte". Nomos, Baden-Baden

Armin von Bogdandy is Director at the Max Planck Institute for Comparative Public Law and International Law, Heidelberg. 
Open Access This chapter is licensed under the terms of the Creative Commons Attribution 4.0 International License (http://creativecommons.org/licenses/by/4.0/), which permits use, sharing, adaptation, distribution and reproduction in any medium or format, as long as you give appropriate credit to the original author(s) and the source, provide a link to the Creative Commons license and indicate if changes were made.

The images or other third party material in this chapter are included in the chapter's Creative Commons license, unless indicated otherwise in a credit line to the material. If material is not included in the chapter's Creative Commons license and your intended use is not permitted by statutory regulation or exceeds the permitted use, you will need to obtain permission directly from the copyright holder. 